\section{Effectiveness of Flame for Preplant Pest Management in Leaf Vegetable Fields}

\author{
Wenlei Guo ${ }^{1}$, Li Feng ${ }^{1}$, Dandan Wu ${ }^{1}$, Chun Zhang ${ }^{1}$, \\ and Xingshan Tian $^{1}$
}

ADDITIONAL INDEX WORDs. flaming machine, insect pest, paraquat, southern China, thermal weeding

SUMMARY. Widespread herbicide-resistant weeds and severe insect pest infestations pose a challenge to the preplant pest management (PPPM) strategy currently in use in leaf vegetable fields in southern China. The aim of this study was to develop a new weed and insect control method for use before planting leaf vegetables in southern China. Two flaming machines (a tractor mounted and a trolley flaming machine) were designed, and their efficacies for the control of insect and weed pests were evaluated and compared in two field trials. With liquefied petroleum gas (LPG) at $101 \mathrm{~kg} \cdot \mathrm{ha}^{-1}$, flaming machines reduced plant numbers by $86.7 \%$ to $98.8 \% 2$ days after treatment (DAT), which was equal to or higher than the reduction after application of paraquat at $900 \mathrm{~g} \cdot \mathrm{ha}^{-1}$. Some weed species, especially awnless barnyard grass (Echinochloa colona) and goosegrass (Eleusine indica), regrew at 7 DAT, resulting in a decrease in control efficacy. Flaming machines also reduced the number of diamondback moth (Plutella xylostella) larvae by $83.0 \%$ to $88.2 \%$ and the number of adult striped flea beetles (Phyllotveta striolata) by $64.9 \%$ to $80.9 \%$. This is the first report on flaming treatment in China to show that this method is a promising alternative to chemical pesticides for PPPM in leaf vegetable fields.

$\mathrm{G}$ uangdong Province, located in southern China, has long been an important vegetable production center, exporting various vegetables to Hong Kong every year. In 2016, the vegetable-growing area in Guangdong Province reached 1.41 million hectares and $\approx 50 \%$ of that area was grown in leaf vegetables (Lan et al., 2018). Many leaf vegetable crops, such as flowering cabbage (Brassica parachinensis), cabbage mustard (Brassica alboglabra), and swamp cabbage (Ipomoea aquatica), are grown continuously in the same field due to the high demand, sufficient natural sources of light, heat,

Received for publication 6 Mar. 2019. Accepted for publication 12 June 2019

Published online 17 September 2019

${ }^{1}$ Plant Protection Research Institute, Guangdong Academy of Agricultural Sciences/Guangdong Provincial Key Laboratory of High Technology for Plant Protection, Guangzhou 510640, China

This research was funded by the Science and Technology Planning Project of Guangdong Province of China (2014A020208048). We thank Guoqi Chen (Yangzhou University) for his assistance and advice in the experiments. We also thank Chaoxian Zhang (Institute of Plant Protection, Chinese Academy of Agricultural Sciences) for his useful and insightful comments on draft versions of the article.

X.T. is the corresponding author. E-mail: 1070470768@ qq.com.

This is an open access article distributed under the $\mathrm{CC}$ BY-NC-ND license (https://creativecommons.org/ licenses/by-nc-nd/4.0/).

https://doi.org/10.21273/HORTTECH04341-19 and water in the subtropical region, and limited arable land per farmer (Feng et al., 2015). Unsurprisingly, vegetable production areas are infested with various insect pests, plant diseases and weeds throughout the year in the region (Liu et al., 2014; Shen et al., 2018).

To ensure a good harvest, necessary control strategies, particularly chemical measures, are implemented mainly in two stages: before cropping and during the crop-growing season. For example, in the crop-growing season, spinetoram and cyantraniliflea beetle, diamondback moth, and tobacco cutworm (Spodoptera litura) (Hong et al., 2017; Li et al., 2015), and pendimethalin and quizalofop-pprole are applied to control striped ethyl are applied to control some annual weeds (Chen et al., 2015). In addition, vegetable growers usually take some measures for PPPM (Mao et al., 2016). In Guangdong Province, farmers typically apply burn-down herbicides (e.g., paraquat and glyphosate) to manage vigorously growing weeds and stubbles and then perform shallow tillage with a rotary cultivator (Chen et al., 2015). However, some problems are inevitable with this PPPM method. First, some important insect pests, such as striped flea beetle and diamondback moth, will not be controlled, which introduces a significant pest source to the next crop. The pests require numerous applications of various insecticides per season to produce acceptable vegetables. Second, both insect pests and weeds are prone to developing resistance to chemical pesticides with repeated applications. In China, the diamondback moth has evolved resistance to many classes of insecticides, including avermectins, chlorantraniliprole, spinosad, and indoxacarb (Wang and Wu, 2012; Wang et al., 2013; Xia et al., 2014). In addition, there have been several reports concerning paraquat and glyphosate resistance in goosegrass and horseweed (Conyza canadensis) in China (An et al., 2014; Chen et al., 2017; Song et al., 2011; Zhang et al., 2015). In this context, farmers have to increase the rates of these pesticides or switch to newly developed pesticides, which increases the control cost substantially. Third, the public demands alternatives due to increasing concerns about food security and a heightened awareness of environmental impacts. Thus, new alternative pest management techniques

\begin{tabular}{|c|c|c|c|}
\hline \multicolumn{4}{|l|}{ Units } \\
\hline \multicolumn{4}{|l|}{$\begin{array}{l}\text { To convert U.S. } \\
\text { multiply by }\end{array}$} \\
\hline 0.4047 & acre $(s)$ & ha & 2.4711 \\
\hline 0.3048 & $\mathrm{ft}$ & $\mathrm{m}$ & 3.2808 \\
\hline 0.0929 & $\mathrm{ft}^{2}$ & $\mathrm{~m}^{2}$ & 10.7639 \\
\hline 9.3540 & gal/acre & $\mathrm{L} \cdot \mathrm{ha}^{-1}$ & 0.1069 \\
\hline 2.54 & inch(es) & $\mathrm{cm}$ & 0.3937 \\
\hline 25.4 & inch(es) & $\mathrm{mm}$ & 0.0394 \\
\hline 0.4536 & $\mathrm{lb}$ & $\mathrm{kg}$ & 2.2046 \\
\hline 1.1209 & $\mathrm{lb} / \mathrm{acre}$ & $\mathrm{kg} \cdot \mathrm{ha}{ }^{-1}$ & 0.8922 \\
\hline 1.6093 & $\mathrm{mph}$ & $\mathrm{km} \cdot \mathrm{h}^{-1}$ & 0.6214 \\
\hline 70.0532 & $\mathrm{oz} /$ acre & $\mathrm{g} \cdot \mathrm{ha}^{-1}$ & 0.0143 \\
\hline 6.8948 & psi & $\mathrm{kPa}$ & 0.1450 \\
\hline$\left({ }^{\circ} \mathrm{F}-32\right) \div 1.8$ & ${ }^{\circ} \mathrm{F}$ & ${ }^{\circ} \mathrm{C}$ & $\left({ }^{\circ} \mathrm{C} \times 1.8\right)+32$ \\
\hline
\end{tabular}


are needed for PPPM in leafy vegetable fields.

Flaming, one of the most important nonchemical methods for crop protection, is successfully used for controlling weeds, insects, soilborne nematodes, and pathogens mainly in the production of organic crops, such as maize (Zea mays), apple (Malus domestica), and vegetables (Agnello et al., 2017; Laguë et al., 1999; Mao et al., 2016; Stepanovic et al., 2016; Vincent et al., 2003). In addition, it is a potential measure to be applied to conventional crops as the problems with chemical pesticides (increasing price, environmental pollution and pest resistance) increase (Stepanovic et al., 2016). Flame controls the pests by overheating them rather than burning them. Most flaming machines use propane or liquefied petroleum gas as fuel, and the flame temperature can exceed $1000{ }^{\circ} \mathrm{C}$, which rapidly raises the temperature of the pest (Datta and Knezevic, 2013; Knezevic et al., 2014). The position and protection mechanism of the growing point and the ability to regrow after the flame treatment are closely related to the thermosensitivity of plants. In addition, the thermal tolerance of the pests increases with increasing body size (Ulloa and Knezevic, 2010; Ulloa et al., 2010). A propane dose of 60 $\mathrm{kg} \cdot \mathrm{ha}^{-1}$ provided up to $80 \%$ to $90 \%$ control of many annual broadleaf and grass species, and a propane dose of $120 \mathrm{~kg} \cdot \mathrm{ha}^{-1}$ is able to control most weeds in the flowering stage (Ulloa and Knezevic, 2010; Ulloa et al., 2010).

Although flaming has a wide range of uses, most reports focus on its application for the control of weeds, insects, or pathogens separately (Kanellou et al., 2017; Sivesind et al., 2012). In fact, flaming can play an important role in PPPM in leaf vegetable fields. The advantages include that 1) flaming takes effect quickly, which may save several days for preparing for the next growing season; 2) flaming kills weedy plants and insect pests simultaneously (Laguë et al., 1997), and thus reduces herbicide and insecticide use; and 3 ) flaming can be used to control tolerant or resistant pests (Datta and Knezevic, 2013). Research groups worldwide have developed different types of flaming equipment (Brainard et al., 2013;
Raffaelli et al., 2013). However, the flaming machines and the burners reported in the literature are often not suitable or efficient for PPPM in leaf vegetable fields. Moreover, there are no reports on the effect of flaming on weed and insect controls in China. Therefore, the objectives of this study were to 1) describe two flaming machines designed for PPPM in leafy vegetable fields and 2) evaluate the performance of flame treatment on weeds and insect pests in field trials.

\section{Materials and methods}

Flaming machines. Two flaming machines, including a tractor mounted flaming machine (TMFM) and a trolley flaming machine (TFM), were designed and built at the Plant Protection Research Institute of Guangdong Academy of Agricultural Sciences, Guangzhou, China (lat. 238 $8^{\prime} 54.74^{\prime \prime} \mathrm{N}$, long. $\left.113^{\circ} 20^{\prime} 33.73^{\prime \prime} \mathrm{E}\right)$. The TMFM was designed for large-scale farms, and the TFM was more suitable for smaller farms. The high-temperature flame is generated by LPG, which heats weeds and insect pests instantly.

The TMFM needs to be connected to a common tractor by the three-point hitch when in use. It is equipped with four LPG tanks (15 or $25 \mathrm{~kg}$ ) and 13 burners, providing a working width of $2.6 \mathrm{~m}$ (Fig. 1). The burners are installed at an angle of $45^{\circ}$ to the ground, and the height of the burners can be easily adjusted from 20 to $50 \mathrm{~cm}$ off the ground.

The machine is equipped with a heat exchange system that allows good heat exchange, thus recovering energy. Four LPG tanks are placed inside a hopper that contains water. The water is heated by means of the exhaust, which passes through an iron tube placed on the machine frame and above the burners. All the LPG tanks are equipped with a pressure regulator to deliver stable outlet pressure for the burners. The pressure regulator is connected to a control system consisting of two manual valves that allow the LPG feed to be adjusted.

The trolley flaming machine is designed mainly to be used in small fields and plots, and it is more convenient for making tight turns in the field. It has the same burner and LPG control system as the mounted flaming machine. This machine (Fig.
2 ) is driven by a walking operator and equipped with two pneumatic wheels to easily carry an LPG tank (total weight of $\approx 30 \mathrm{~kg}$ ). The tank is tightly attached to an arc baffle. The trolley machine is equipped with five burners to provide a total working width of $1.04 \mathrm{~m}$.

SPECIFICATIONS OF THE BURNER. The burners of the flaming machines are designed to be suitable for land cleaning in leaf vegetable fields. The burners are made from stainless steel and characterized by a special shielded cover (Fig. 3). The upper part of the cover is conical with six air breathers around it, while the other half of the cover is flattened with an about rectangular cross-section. A heat-resistant metal mesh is designed and placed inside the shielded cover. The working pressure of the burner was set at 250 $\mathrm{kPa}$, under which the flame temperature reached as high as $1040{ }^{\circ} \mathrm{C}$ during the experiment (measured by South China National Center of Metrology, Guangzhou, China). The gas consumption is $2.1 \mathrm{~kg} \cdot \mathrm{h}^{-1}$ per burner at $250 \mathrm{kPa}$.

Field trial location. Field trials were conducted at an experimental station in Baiyun district, Guangzhou (lat. 2318'2.02"N, long. $113^{\circ} 16^{\prime} 30.45^{\prime \prime} \mathrm{E}$, altitude $15 \mathrm{~m}$, loam with $2.2 \%$ organic matter and $\mathrm{pH} 6.0$ ), during vegetable growing seasons. Trial 1 was performed on 18 Oct. 2017, and Trial 2 was performed on 11 Apr. 2018. The air temperature, relative humidity, and rainfall during the experimental periods are shown in Table 1. Flowering cabbage had been harvested $3 \mathrm{~d}$ before treatment. Many weed species and insect pests could be found in the fields. The weed community was composed of a mixture of grass, sedges (Cyperaceae), and broadleaf weed species, with most at the flowering and fruiting stages. Rice flatsedge (Cyperus iria) was the most common weed species, followed by awnless barnyard grass, green amaranth (Amaranthus lividus), goosegrass, and false daisy (Eclipta prostrata). Moreover, flowering cabbage stubbles also inundated the fields and provided enough food for striped flea beetle adults and larvae of diamondback moth larvae, which would be the main pest source for the next crop season.

Trial layout. To compare with conventional method for PPPM, four treatments were included in the 


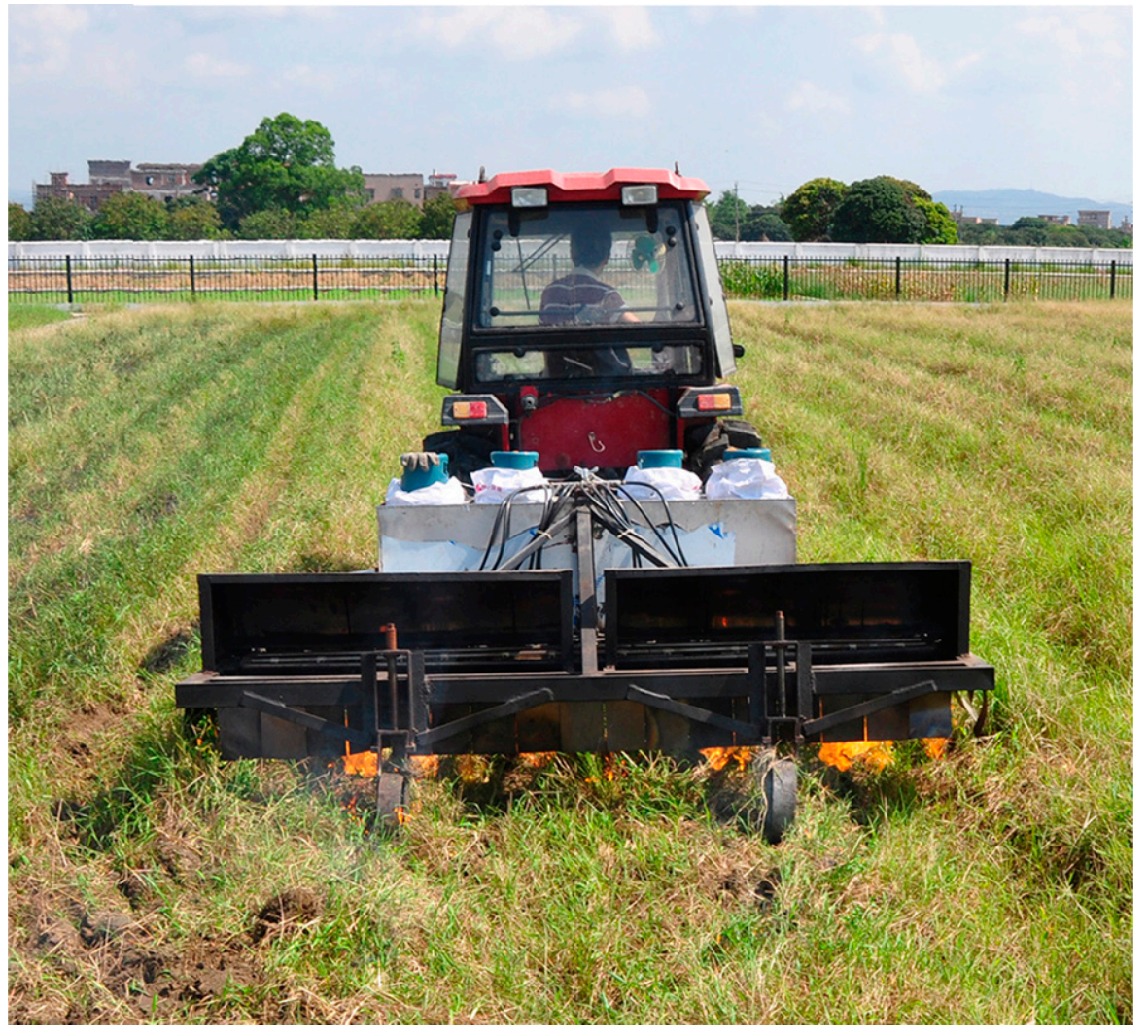

Fig. 1. Mounted flaming machine coupled to a common tractor by a three-point hitch.

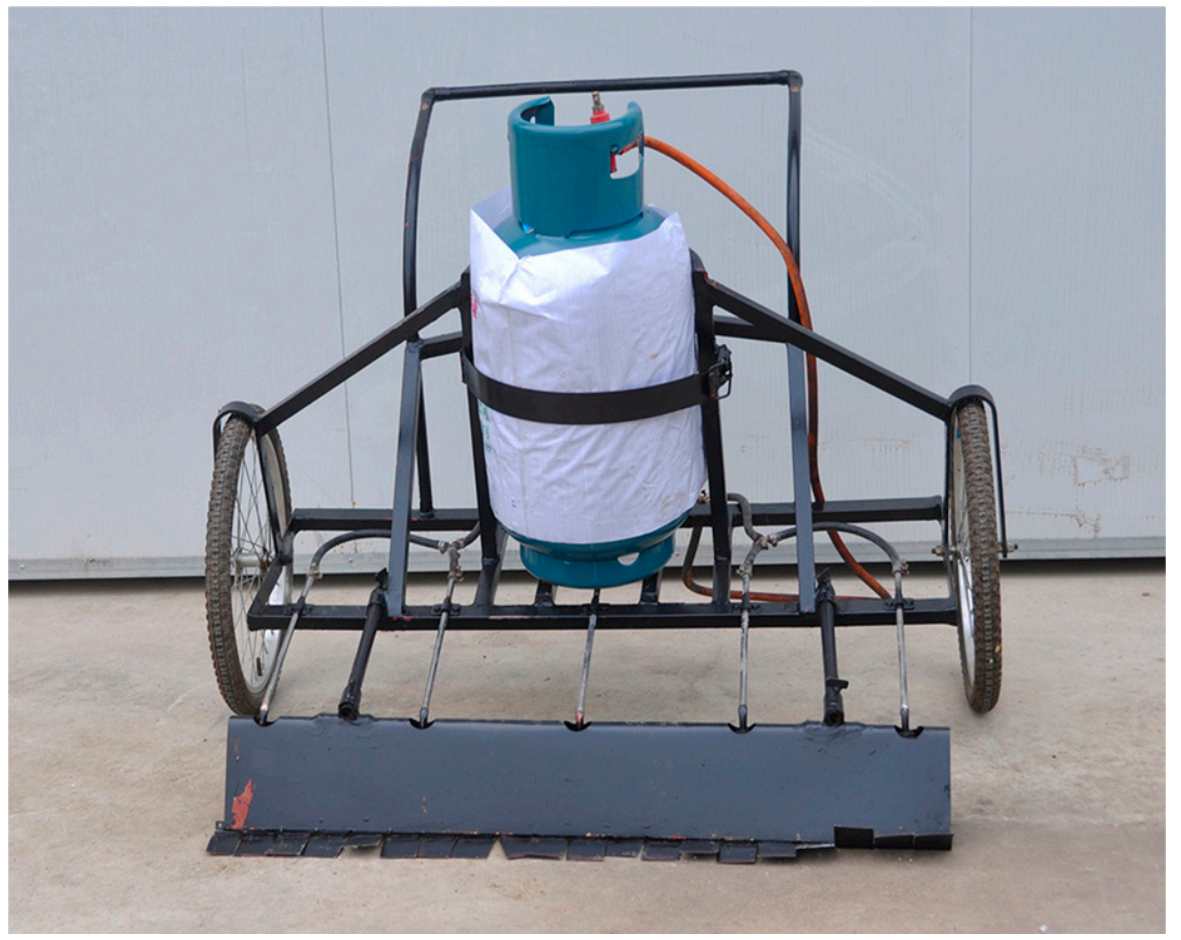

Fig. 2. Trolley flaming machine equipped with five burners used for broadcast flaming.

experiments: a TMFM treatment, a TFM treatment, $900 \mathrm{~g} \cdot \mathrm{ha}^{-1}$ paraquat (20\% water soluble gel; Nanjing Red Sun Biochemistry Co., Nanjing, $\mathrm{km} \cdot \mathrm{h}^{-1}$, which resulted in an $\mathrm{LPG}$ dose rate of $101 \mathrm{~kg} \cdot \mathrm{ha}^{-1}$, and the burners were set at $35 \mathrm{~cm}$ aboveground level. Paraquat was applied by using a backpack sprayer (HD 400; Agrolex, Singapore), with one flat fan nozzle (TeeJet 11002 flat fan nozzle; Spraying Systems, Wheaton, IL), which was calibrated to deliver $450 \mathrm{~L} \cdot \mathrm{ha}^{-1}$ at $300 \mathrm{kPa}$ pressure. Experiments were conducted from 0930 to $1200 \mathrm{HR}$, and the weather is shown in Table 1 . The treatments were assigned to plots $\left(130 \mathrm{~m}^{2}, 5.2 \times\right.$ $25 \mathrm{~m}$ ) in a completely randomized design with four replicates.

Data collection. The numbers of striped flea beetle adults and diamondback moth larvae were counted 30 min after flame treatment. In each plot, five points were selected in a diagonal sampling pattern and three plants were sampled per point by visual inspection (including the reverse and obverse side of the leaves) in the field.

Three quadrats $(1.0 \times 1.0 \mathrm{~m})$ were randomly selected from each plot. To find a quick way to eliminate pests in between crops, weed numbers were counted at 2 and $7 \mathrm{~d}$ after treatment. At 7 DAT, the aboveground parts of the weeds were cut and the fresh weights were recorded.

Statistical analysis. The efficacy in controlling insect pests or weeds was calculated according to the following equation:

$$
\Upsilon=\frac{X_{1}-X_{2}}{X_{1}} \times 100
$$

where $\Upsilon$ represents the control efficacy, $X_{1}$ represents the number or weight in untreated plots, and $X_{2}$ represents the number or weight in flaming or paraquat treatment plots.

All data (the insect numbers were log transformed, and the weed control efficacies were arcsine-square-root transformed before analysis) were subjected to analysis of variance with means separated using Fisher's protected least significant difference test. Significance was set at $P<0.05$ and statistical analysis were performed in SPSS (version 21 for Windows; IBM SPSS, Armonk, NY).

\section{Results}

Insect PESt control. Flaming our experiment, the TFM was pushed forward (flame in the front). The machines' forward speed was 1 

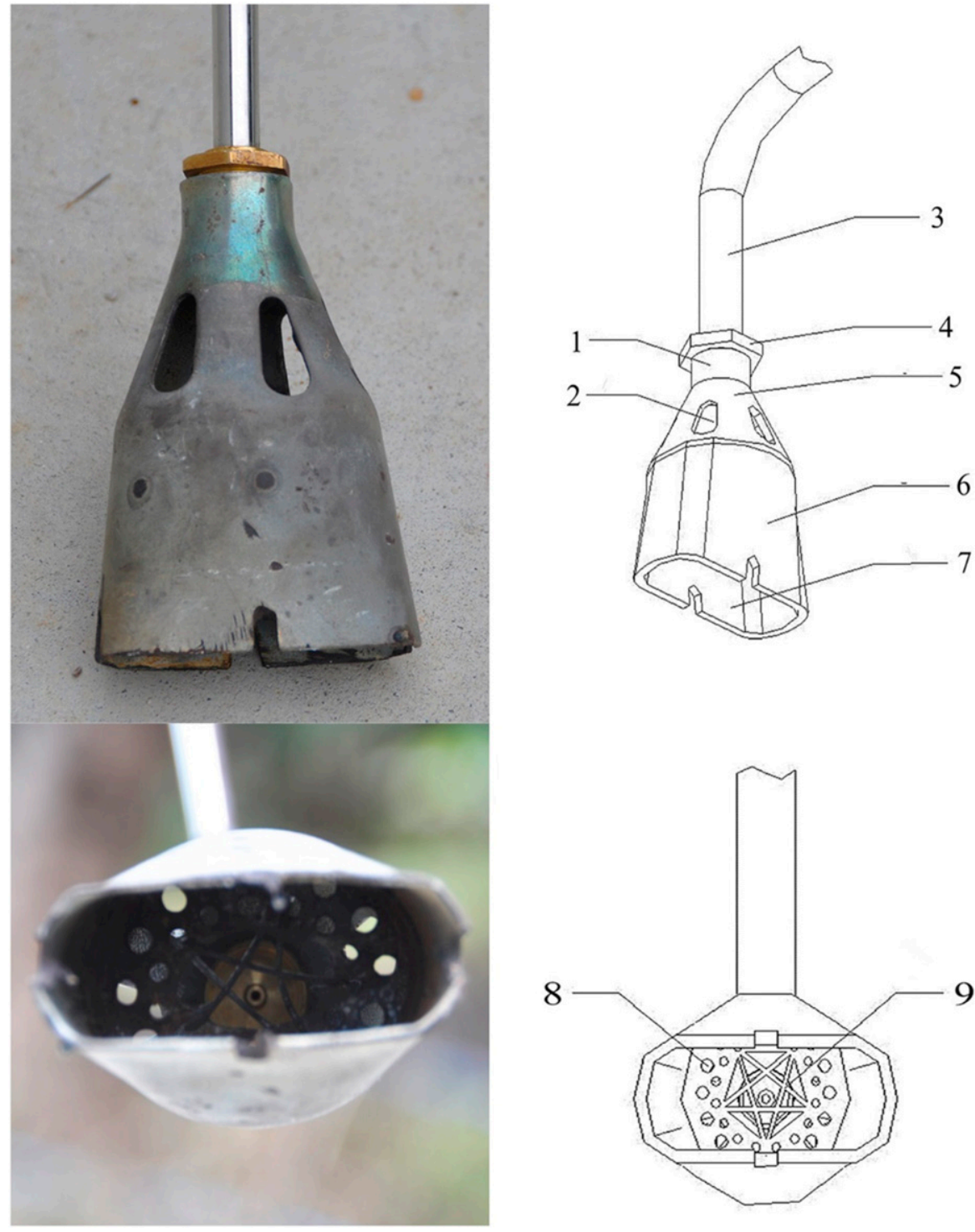

Fig. 3. Photographs and diagrams of the burner: (1) inlet pipe, (2) air breather, (3) gas pipe, (4) joint, (5) cone-shaped part, (6) flat part, (7) nozzle exit, (8) shielded cover, and (9) pentagonal reseau.

striped flea beetle compared with the untreated control (Table 2). The TMFM treatment reduced diamondback moth larvae numbers in Trials 1 and $2 \times 84.8 \%$ and $83.0 \%$, respectively. The TFM treatment reduced diamondback moth larvae numbers in Trials 1 and $2 \times 88.2 \%$ and $86.7 \%$, respectively. However, these results for the two flaming machines were not significantly different $(P<0.05)$ in each trial.

Flaming can be used to control striped flea beetle adults by instantaneous heating, but the control efficacy was different according to the machine type. With LPG application at $101 \mathrm{~kg} \cdot \mathrm{ha}^{-1}$, striped flea beetle adults were $67.5 \%$ and $64.9 \%$ controlled by TMFM treatment in Trials 1 and 2 , respectively (Table 2). The TFM treatment provided significantly higher control efficacy than TMFM treatment, and striped flea beetle adults were $80.9 \%$ and $79.3 \%$ controlled in Trials 1 and 2 , respectively.

Weed Control. Weed species displayed different sensitivities to flaming and paraquat treatments (Fig. 4). The grass weeds and flowering cabbage stubble exhibited higher tolerance than broadleaf or sedge weeds. For example, there were no significant differences between flaming and paraquat treatments for the control of rice flatsedge and green amaranth, in which more than $95 \%$ of plants were dried up at 2 DAT, but for flowering cabbage stubble, the control effects decreased to $86.7 \%$ under flaming treatments and to $72.2 \%$ under paraquat treatment (Fig. 4). Flaming treatments showed significantly higher efficacy than paraquat treatment in controlling awnless barnyard grass, goosegrass and flowering cabbage, but there were no significant differences between TMFM and TFM.

At 2 DAT, most weeds were dried up, which means that both flame and paraquat worked quickly. In fact, flaming treatment took effect

Table 1. Air temperature, average relative humidity, and rainfall at the experimental site at Baiyun district, Guangzhou, China during Trial 1 (2017) and Trial 2 (2018).

\begin{tabular}{|c|c|c|c|c|c|c|c|c|c|c|}
\hline \multirow[b]{3}{*}{ Days after treatment } & \multicolumn{6}{|c|}{ Air temp $\left({ }^{\circ} \mathbf{C}\right)^{z}$} & \multirow{2}{*}{\multicolumn{2}{|c|}{$\begin{array}{c}\text { Avg relative } \\
\text { humidity (\%) }\end{array}$}} & \multirow{2}{*}{\multicolumn{2}{|c|}{$\operatorname{Rainfall}(\mathrm{mm})^{\mathrm{z}}$}} \\
\hline & \multicolumn{2}{|c|}{ Maximum } & \multicolumn{2}{|c|}{ Minimum } & \multicolumn{2}{|c|}{ Mean } & & & & \\
\hline & Trial 1 & Trial 2 & Trial 1 & Trial 2 & Trial 1 & Trial 2 & Trial 1 & Trial 2 & Trial l & Trial 2 \\
\hline 1 & 25.8 & 30.3 & 21.2 & 23.5 & 22.5 & 25.8 & 70 & 73 & 0 & 0 \\
\hline 2 & 26.1 & 29.7 & 20.0 & 23.2 & 22.1 & 25.4 & 66 & 72 & 0 & 0 \\
\hline 3 & 26.4 & 29.2 & 18.6 & 20.5 & 21.5 & 24.3 & 66 & 85 & 0 & 4.9 \\
\hline 6 & 27.6 & 21.5 & 16.6 & 15.8 & 21.0 & 18.6 & 71 & 70 & 0 & 0 \\
\hline 7 & 28.1 & 25.3 & 16.8 & 18.7 & 20.9 & 20.5 & 76 & 74 & 0 & 0 \\
\hline
\end{tabular}

${ }^{\mathrm{z}}\left(1.8 \times{ }^{\circ} \mathrm{C}\right)+32={ }^{\circ} \mathrm{F}, 1 \mathrm{~mm}=0.0394$ inch. 
Table 2. Effect of flaming treatments with $101 \mathrm{~kg} \cdot \mathrm{ha}^{-1}(90.1 \mathrm{lb} / \mathrm{acre})$ liquefied petroleum gas on diamondback moth larvae (DML) and striped flea beetle adults (SFBA).

\begin{tabular}{|c|c|c|c|c|c|}
\hline \multirow[b]{2}{*}{ Trials } & \multirow[b]{2}{*}{ Treatments ${ }^{\mathrm{z}}$} & $\mathrm{DML}(\text { no. })^{\mathrm{y}}$ & SFBA (no.) ${ }^{y}$ & \multicolumn{2}{|c|}{ Control (\%) } \\
\hline & & \multicolumn{2}{|c|}{ Mean \pm SE } & $\overline{\mathrm{DML}}$ & SFBA \\
\hline \multirow[t]{3}{*}{ Trial 1, 2017} & Untreated & $28.9 \pm 4.0 \mathrm{a}^{\mathrm{x}}$ & $59.4 \pm 6.0 \mathrm{a}$ & - & - \\
\hline & TMFM & $4.4 \pm 1.4 \mathrm{~b}$ & $19.3 \pm 2.1 \mathrm{~b}$ & 84.8 & 67.5 \\
\hline & TFM & $3.4 \pm 1.5 \mathrm{~b}$ & $11.4 \pm 2.5 \mathrm{c}$ & 88.2 & 80.9 \\
\hline \multirow[t]{3}{*}{ Trial 2, 2018} & Untreated & $16.5 \pm 2.6 \mathrm{a}$ & $72.7 \pm 7.4 \mathrm{a}$ & - & - \\
\hline & TMFM & $2.8 \pm 1.2 \mathrm{~b}$ & $25.6 \pm 5.0 \mathrm{~b}$ & 83.0 & 64.9 \\
\hline & TFM & $2.2 \pm 1.2 \mathrm{~b}$ & $15.1 \pm 2.4 \mathrm{c}$ & 86.7 & 79.3 \\
\hline
\end{tabular}

${ }^{\mathrm{z}} \mathrm{TMFM}=$ tractor mounted flaming machine; TFM $=$ trolley flaming machine.

${ }^{y}$ Data (means of four plots) were collected $30 \mathrm{~min}$ after flame treatment.

${ }^{x}$ Means in the same column followed by the same letter are not significantly different within trial according to Fisher's protected least significant difference test $(P<0.05)$.

more rapidly than paraquat treatment and resulted in wilt within $3 \mathrm{~h}$ (data not shown). This is also shown in the fact that paraquat killed more flowering cabbage stubbles at 7 DAT than at 2 DAT.

Both flaming and paraquat treatment showed poor persistence. Some newly developed tissues were observed at $7 \mathrm{DAT}$, resulting in a decrease in control efficacy on some weed species (Fig. 4). For example, flaming treatments showed much larger declines in efficacy than paraquat treatment in the control of awnless barnyard grass and goosegrass (Fig. 4). However, flaming treatments still displayed similar or higher control efficacies on most weed species than paraquat treatment at $7 \mathrm{DAT}$ (Fig. 4). As shown in Fig. 4, the effect of treatment on fresh weight was more obvious than that on plant numbers during the same period, which indicated that the biomass of some surviving plants was reduced compared with that in the untreated control.
In our experiment, the weed control efficacies of Trial 2 (2018) were consistently lower than those of Trial 1 (2017). Considering that the air temperatures were similar during the experiment periods in 2017 and 2018 (Table 1), the difference in rainfall $(50.5 \mathrm{~mm}$ in 2018 and $0 \mathrm{~mm}$ in 2017) was probably a dominant factor leading to the difference in control efficacies. Increased rainfall and higher air humidity conditions were likely to have a negative effect on weed control with flaming treatment according to our data.

\section{Discussion}

Flaming has been reported as a promising method against a variety of pests, such as weeds, soilborne nematodes, fungal and bacterial pathogens and insects (Mao et al., 2016; Sivesind et al., 2012; Vincent et al., 2003). Our flaming machine could generate combustion temperatures as high as $1040{ }^{\circ} \mathrm{C}$, which was hot enough to heat pests rapidly. It was reported that the legs of colorado potato beetles (Leptinotarsa decemlineata) could be irreparably damaged
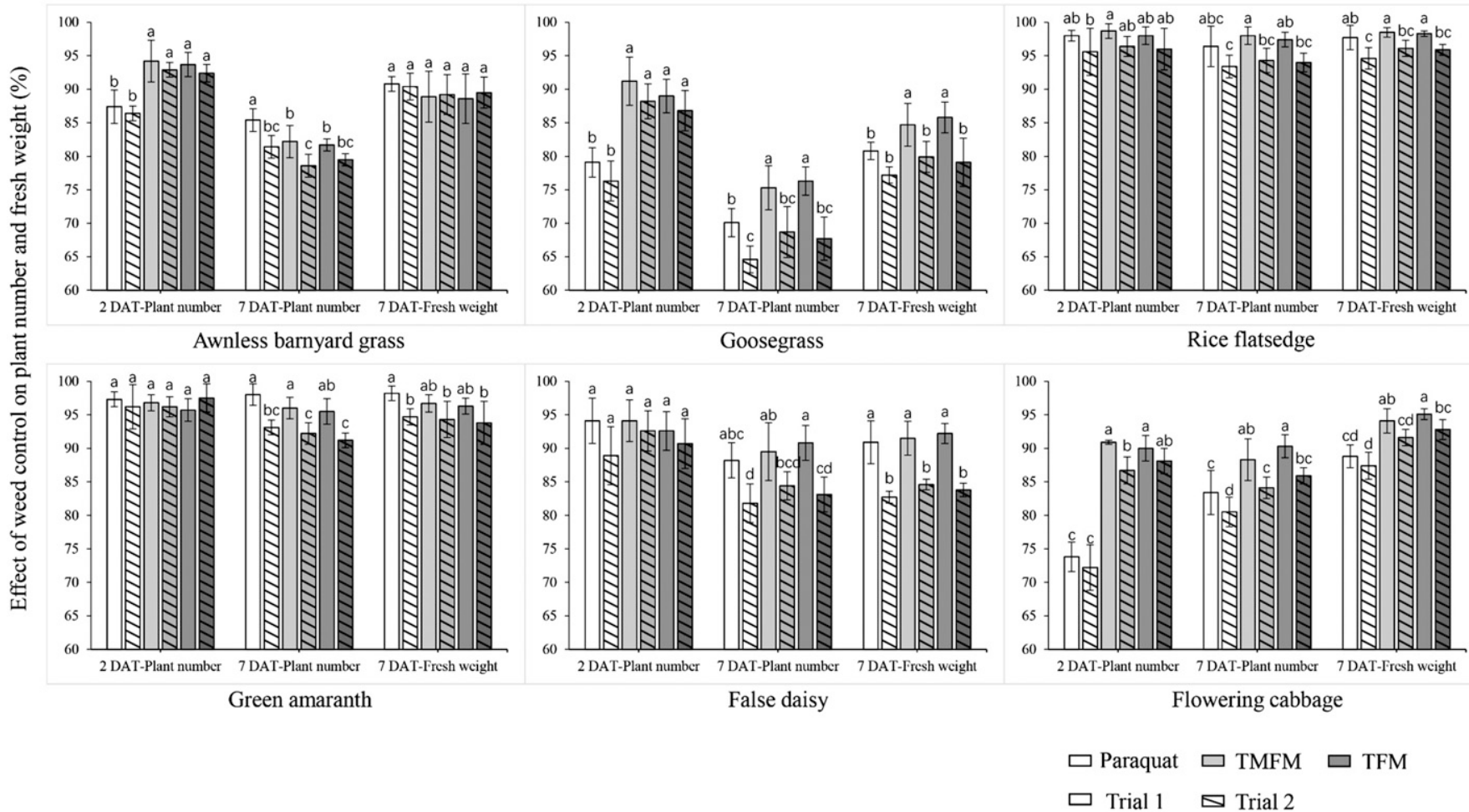

Fig. 4. Reduction in plant number and fresh weight following paraquat $\left[900 \mathrm{~g} \cdot \mathrm{ha}^{-1}(12.8 \mathrm{oz} / \mathrm{acre})\right]$ and flaming [ $101 \mathrm{~kg} \cdot \mathrm{ha} \mathrm{a}^{-1}$ $(90.1 \mathrm{lb} /$ acre) liquefied petroleum gas] treatments at 2 and $7 \mathrm{~d}$ after treatment (DAT); TMFM = tractor-mounted flaming machine; TFM = trolley flaming machine. Different letters are significantly different $(P<0.05)$ according to Fisher's protected least significant difference test. 
at 68 to $75^{\circ} \mathrm{C}$ (Pelletier et al., 1995). Similarly, the leaves and stems of plants are inactivated by exposure at 95 to $100{ }^{\circ} \mathrm{C}$ for more than $0.1 \mathrm{~s}$ (Ascard et al., 2007). There are six air breathers around the cover of the burner that increase the ventilation volume and combust the fuel more completely. Moreover, the heat-resistant metal mesh prevents the weeds and other materials from putting out the flame. These designs make the burner more suitable for use in leaf vegetable fields. The field trial results showed that the TFM treatment displayed higher control efficacy on striped flea beetle than the TMFM treatment. Our preliminary results (data not shown) also showed that the control efficacies of flaming on some insect pests varied between different advance modes: pushing (flame in the front) or pulling (people in the front). The authors estimate that some highly mobile insects, such as the striped flea beetle, may flee before flaming treatment when the machine is pulled in the field, whereas push-flaming may reduce the chances of escape and thus kill more pests.

In our experiment, flaming treatments showed a broad spectrum of weed control, which is of great importance in the management of herbicide-resistant/tolerant weeds and stubbles. In Trials 1 and 2, flaming treatments displayed higher efficacy on awnless barnyard grass, goosegrass and flowering cabbage than paraquat treatment at $2 \mathrm{DAT}$. Indeed, quickaction was an impressive characteristic of the flaming treatments, and it could greatly shorten the interval between two growing seasons compared with the interval required with most chemical pesticides. A similar advantage was shown in controlling soilborne nematodes and pathogens with flame soil disinfestation (Mao et al., 2016). The PPPM has a relatively lower demand for selectivity than in-season pest management, and thus, the LPG dose can be improved to gain a better control effect without crop injury. As an alternative to chemical pest control, flame treatment eliminates anxiety over direct residual effects on soil, water, and food quality and reduces the reliance on pesticides (Datta and Knezevic, 2013 ). It was estimated that insecticide use could be reduced by $20 \%$ in the next growing season because of the lower initial number of pests.

Nevertheless, the flaming technology used in this study needs further research. First, some weed species are prone to regrow after flaming treatment, especially during periods of continual rainy days with high humidity. According to our experiments, it appeared that flaming treatment had better effects on annual broadleaf weeds than on annual grass weeds, which was in accordance with the results of some previous studies (Merfield et al., 2017; Sivesind et al., 2012). It was reported that the most important factor distinguishing sensitive and tolerant species was the ability of weed plants to regrow after the flaming treatment (Raffaelli et al., 2013). At the plant individual level, the physical location and the protection mechanism of the growing point have remarkable impacts on the ability to regrow (Ulloa and Knezevic, 2010; Ulloa et al., 2010, 2012). Irreversibly damaging the growing points should be highlighted in the development of flaming technology. Raising the flame temperature through improvement of the burners and conducting the flaming treatment as early as possible after harvest may contribute to this goal. Second, compared with being dragged forward, the TFM performed better in controlling insect pests when it was pushed. In this study, the TMFM was mounted on the rear of the tractor, but it can be improved by mounting it on the front under the premise of the security of the operator. Third, although there have been many reports on flaming treatment, few studies have focused on the long-term effects of flaming on weed communities, insect pest populations, soil seed banks, and the development of heat resistance. Last, the control cost of flaming treatment ( $\$ 89$ to $\$ 112$ per hectare) is higher than that of paraquat treatment ( $\$ 22$ to $\$ 33$ per hectare). In China, however, paraquat in any form (including water-soluble gel used in this study) will be prohibited completely starting in Sept. 2020. In fact, an increasing number of farmers are beginning to replace paraquat with glufosinate ( $\$ 68$ to $\$ 90$ per hectare). Considering the earnings from planting leaf vegetables, this price difference would be acceptable to most farmers.

\section{Conclusions}

Flaming is a novel thermal-based method of simultaneously controlling weeds and insect pests in China. Both the TMFM and the TFM (with LPG at $101 \mathrm{~kg} \cdot \mathrm{ha}^{-1}$ ) effectively controlled most weed species at 2 DAT, although some species regrew at 7 DAT. As a new method of PPPM in China, flaming treatment may dramatically reduce herbicide and insecticide usage in the production of leaf vegetables. Moreover, it is likely that flaming can also be applied to other crops, such as orchard crops, maize, and onion (Allium cepa). In the near future, more attention should be paid to the improvement of the flaming machine and the long-term effects of flaming on weeds, insects, natural enemies, microorganisms, and other aspects. Overall, flaming treatment can be used as an alternative to chemical pesticide for PPPM in leaf vegetable fields in southern China.

\section{Literature cited}

Agnello, A., K. Cox, J. Lordan, P. Francescatto, and T. Robinson. 2017. Comparative programs for arthropod, disease and weed management in New York organic apples. Insects 8:96.

An, J., X. Shen, Q. Ma, C. Yang, S. Liu, and Y. Chen. 2014. Transcriptome profiling to discover putative genes associated with paraquat resistance in goosegrass (Eleusine indica L.). PLoS One 9:e99940.

Ascard, J., P.E. Hatcher, B. Melander, and M.K. Upadhyaya. 2007. Thermal weed control. CAB Intl., Wallingford, UK.

Brainard, D.C., P.R. Edward, E.R. Haramoto, J.M. Luna, and R. Anusuya. 2013. Weed ecology and nonchemical management under strip-tillage: Implications for northern U.S. vegetable cropping systems. Weed Technol. 27:218-230.

Chen, G., L. Feng, and X. Tian. 2015. Influences of different weed control practices on hot-season vegetable-field weed communities in south China. Acta Ecol. Sin. 35:7444-7453.

Chen, J., H. Huang, S. Wei, Z. Huang, X. Wang, and C. Zhang. 2017. Investigating the mechanisms of glyphosate resistance in goosegrass (Eleusine indica (L.) Gaertn.) by RNA sequencing technology. Plant J. 89:407-415.

Datta, A. and S.Z. Knezevic. 2013. Flaming as an alternative weed control method for conventional and organic 
agronomic crop production systems: A review. Adv. Agron. 118:399-428.

Feng, L., G. Chen, X. Tian, H. Yang, M. Yue, and C. Yang. 2015. The hotter the weather, the greater the infestation of Portulaca oleracea: Opportunistic lifehistory traits in a serious weed. Weed Res. 55:396-405.

Hong, W., Y. Wu, J. Wei, and Y. Wu. 2017. Efficiency of cyantraniliprole on Plutella xylostella (L.) and its residual dissipation dynamics in Brassica oleracea. Chinese J. Pesticide Sci. 19:211-216.

Kanellou, E., G. Economou, M. Papafotiou, N. Ntoulas, D. Lyra, E. Kartsonas, and S. Knezevic. 2017. Flame weeding at archaeological sites of the Mediterranean region. Weed Technol. 31:396-403.

Knezevic, S.Z., S. Strahinja, and D. Avishek. 2014. Growth stage affects response of selected weed species to flaming. Weed Technol. 28:233-242.

Laguë, C., J. Gill, N. Lehoux, and G. Péloquin. 1997. Engineering performances of propane flamers used for weed, insect pest, and plant disease control. Appl. Eng. Agr. 13:7-16.

Laguë, C., M. Khelifi, J. Gill, and B. Lacasse. 1999. Pneumatic and thermal control of colorado potato beetle. Can. Biosystems Eng. 41:53-57.

Lan, G., L. Yu, Z. He, X. She, Y. Tang, and M. Deng. 2018. Sensitivity of Colletotrichum higginsianum isolated from Brassica parachinensis to prochloraz in Guangdong Province from 2009 to 2014. Chinese J. Pesticide Sci. 20:249-253.

Li, Z., X. Feng, S. Liu, M. You, and M. Furlong. 2015. Biology, ecology, and management of the diamondback moth in China. Annu. Rev. Entomol. 61:277-296.
Liu, Y., Z. Shi, M.P. Zalucki, and S. Liu. 2014. Conservation biological control and IPM practices in Brassica vegetable crops in China. Biol. Control 68:37-46.

Mao, L., Q. Wang, D. Yan, Y. Li, C. Ouyang, M. Guo, and A. Cao. 2016. Flame soil disinfestation: A novel, promising, non-chemical method to control soilborne nematodes, fungal and bacterial pathogens in China. Crop Prot. 83:90-94.

Merfield, C.N., J.G. Hampton, and S.D. Wratten. 2017. Efficacy of heat for weed control varies with heat source, tractor speed, weed species and size. N. Z. J. Agr. Res. 60:437-448.

Pelletier, Y., C.D. Mcleod, and G. Behnard. 1995. Description of sublethal injuries caused to the colorado potato beetle ( $\mathrm{CO}^{-}$ leoptera: Chrysomelidae) by propane flamer treatment. J. Econ. Entomol. 88:12031205.

Raffaelli, M., L. Martelloni, C. Frasconi, M. Fontanelli, and A. Peruzzi. 2013. Development of machines for flaming weed control on hard surfaces. Appl. Eng. Agr. 29:663-673.

Shen, S., M.D. Day, G. Xu, D. Li, G. Jin, X. Yin, Y. Yang, S. Liu, Q. Zhang, R. Gao, F. Zhang, and R.L. Winston. 2018. The current status of biological control of weeds in southern China and future options. Acta Ecol. Sin. 38:158-164.

Sivesind, E.C., M.L. Leblanc, D.C. Cloutier, P. Seguin, and K.A. Stewart. 2012. Impact of selective flame weeding on onion yield, pungency, flavonoid concentration, and weeds. Crop Prot. 39:45-51.

Song, X.L., J. Wu, H.J. Zhang, and S. Qiang. 2011. Occurrence of glyphosateresistant horseweed (Conyza canadensis) population in China. Agric. Sci. China 10:1049-1055.
Stepanovic, S., A. Datta, B. Neilson, C. Bruening, C.A. Shapiro, G. Gogos, and S.Z. Knezevic. 2016. Effectiveness of flame weeding and cultivation for weed control in organic maize. Biol. Agr. Hort. 32:47-62.

Ulloa, S.M., A. Datta, C. Bruening, G. Gogos, T.J. Arkebauer, and S.Z. Knezevic. 2012. Weed control and crop tolerance to propane flaming as influenced by the time of day. Crop Prot. 31:1-7.

Ulloa, S.M., A. Datta, and S. Knezevic. 2010. Tolerance of selected weed species to broadcast flaming at different growth stages. Crop Prot. 29:1381-1388.

Ulloa, S.M. and S.Z. Knezevic. 2010. Growth stage-influenced differential response offoxtail and pigweed species to broadcast flaming. Weed Technol. 24:319325 .

Vincent, C., G. Hallman, B. Panneton, and F. Fleurat-Lessard. 2003. Management of agricultural insects with physical control methods. Annu. Rev. Entomol. 48:261-281.

Wang, X., S.K. Khakame, C. Ye, Y. Yang, and Y. Wu. 2013. Characterisation of field-evolved resistance to chlorantraniliprole in the diamondback moth, Plutella xylostella, from China. Pest Mgt. Sci. 69:661-665.

Wang, X. and Y. Wu. 2012. High levels of resistance to chlorantraniliprole evolved in field populations of Plutella xylostella. J. Econ. Entomol. 105:1019-1023.

Xia, Y., Y. Lu, J. Shen, X. Gao, H. Qiu, and J. Li. 2014. Resistance monitoring for eight insecticides in Plutella xylostella in central China. Crop Prot. 63:131-137.

Zhang, C., L. Feng, T. He, C. Yang, G. Chen, and X. Tian. 2015. Investigating the mechanisms of glyphosate resistance in goosegrass (Eleusine indica) population from south China. J. Integr. Agr. 14:909-918. 